\title{
Immunohistochemical Comparison of Markers for Wound Healing on Plastic-Embedded and Frozen Mucosal Tissue
}

\author{
Ronald Mai $^{a} \quad$ Tomasz Gedrange $^{b}$ Henry Leonhardt ${ }^{a} \quad$ Nicole Sievers ${ }^{a}$ \\ Günter Lauer ${ }^{\mathrm{a}}$ \\ ${ }^{a}$ Department of Oral and Maxillofacial Surgery, University Hospital Carl Gustav Carus, Technical University of Dresden, \\ Dresden, and ${ }^{b}$ Department of Orthodontics, Preventive and Pediatric Dentistry, Center of Dentistry and Oral Health, \\ Ernst Moritz Arndt University, Greifswald, Germany
}

\section{Key Words}

Cytokeratins $\cdot$ Frozen tissue sections $\cdot$ Human

attached mucosa $\cdot$ Intra-/extracellular protein markers ·

Plastic-embedded mucosa $\cdot$ Wound healing

\begin{abstract}
Immunohistologic investigations of wound healing in human oral mucosa require specific cell biological markers as well as consecutive small biopsies. Small specimens are ideally embedded in plastic (methylmethacrylate, MMA) resin due to their miniature size. This limits the use of antibodies for these markers. In this immunohistochemical study, the distribution of wound healing markers, e.g. cytokeratin (CK), laminin, collagen IV, vimentin, vinculin and fibronectin, were compared between semithin sections of plastic-embedded tissue and frozen sections of mucosal tissue in order to assess their use for future investigations. The antibodies against laminin, collagen IV and CK 1/2/10/11, 5/6, 13, 14, 17, 19 gave comparable staining patterns on cryostat sections of attached mucosa and on semithin sections of MMA-embedded attached mucosa. In the epithelial cell layers, the following distribution of $\mathrm{CK}$ immunostaining was observed: The basal cell layer was positive for CK 5/6, CK 14 and CK 19; the intermediate cell layer for CK 13, CK 17 and CK 1/2/10/11, and the superficial cell layer for CK 13 and CK 1/2/10/11. For most of these antibodies, enzyme digestion with $0.1 \%$ trypsin was
\end{abstract}

adequate for demasking the antigens, except for anti-CK 14, anti-CK 17 and anti-laminin; predigestion with 0.4\% pepsin in $0.01 \mathrm{~N} \mathrm{HCl}$ gave similar staining results. The antibodies against vimentin, vinculin, fibronectin and CK 4 showed no affinity or a reciprocal reaction on the semithin sections. Therefore, the antibodies against CK 1/2/10/11; 5/6; 13; 14; 17, and 19 , as well as the basement proteins laminin and collagen IV are deemed markers suitable on semithin sections of plastic-embedded attached oral mucosa.

Copyright $\odot 2008$ S. Karger AG, Base

\section{Introduction}

Histopathologic diagnostic tools or cell biological markers for the assessment of events during wound healing are extracellular and intracellular proteins, respectively [Becker et al., 1986; Ouhayoun et al., 1990; Carmichael et al., 1991]. Intracellular markers are cytokeratins

\begin{tabular}{ll} 
Abbreviations used in this paper \\
\hline CK & cytokeratin \\
MMA & methylmethacrylate \\
PBS & phosphate-buffered saline
\end{tabular}

Prof. Dr. Dr. Günter Lauer

Department of Oral and Maxillofacial Surgery

University Hospital Carl Gustav Carus

Fetscherstrasse 74, DE-01307 Dresden (Germany)

Tel. +49 351458 4546, E-Mail guenter.lauer@uniklinikum-dresden.de 
(CK), vimentin and vinculin, and extracellular markers are collagen IV, laminin and fibronectin. CK are intermediate filament proteins in the cytoplasm of epithelial cells and part of the cytoskeleton. Twenty different CK polypeptides have been identified in human tissues [Moll et al., 1982], with molecular weights ranging from 40 to 68 $\mathrm{kDa}$. Two different types of CK can be distinguished using electrophoresis: acid and neutral/basic CK. CK show different but distinct distribution patterns in various epithelia as well as within stratified epithelia. In the stratum basale, stratum spinosum, stratum granulosum and stratum corneum [Shabana et al., 1989] characteristic distributions of CK can be found. Hence, they represent specific markers for pathways of epithelial differentiation [Boisnic et al., 1995; Weingaertner et al., 2006].

In gingival epithelium or epithelium of attached mucosa, keratinocytes express CK 1/2/10/11 and 17 in the intermediate (suprabasal) and superficial cell layers according to Kellokoski et al. [1991], and CK 5/6 and 14 predominantly in the stratum basale [Ouhayoun et al., 1990] (basal cell layer according to Kellokoski et al. [1991]). In inflamed gingiva, i.e. in samples of gingivitis or periodontitis, CK 4, 13 and 19 are more frequent [Bosch et al., 1989] as well as an extended distribution of CK 5/6, 14 and 17 in the intermediate layers (stratum spinosum and granulosum), the latter also being characteristic for epithelial hyperproliferation.

Vimentin and vimentin-like proteins can form intermediate filaments and are found in cells of mesenchymal origin, e.g. fibroblasts. However, cultured epithelial cells temporally express vimentin [Alberts et al., 1994]. Vinculin, an intracellular adhesion molecule, connects actin filaments and transmembrane glycoproteins [Alberts et al., 1994].

Collagen IV and laminin are components of the basal membrane [Alberts et al., 1994]. The latter functions as an adhesion molecule between epithelial cells and collagen IV. Fibronectin facilitates cell adhesion to the extracellular matrix [Alberts et al., 1994]. All these proteins play an important role during cell and tissue differentiation [Klein et al., 1990] and are therefore an important tool in the immunohistological pathology.

In order to analyze cell biological events during wound healing, consecutive biopsies from the wound site, ideally from the same patient, are desirable. Especially in the oral cavity, sampling may be limited and biopsies are small. Histological study of small specimens requires a special embedding technique, e.g. with methylmethacrylate (MMA). However, similar to paraffin, the plasticembedding technique may interfere with immunostain- ing and result in loss of antigenic properties [Carmichael et al., 1991; Ten Hacken et al., 1997]. In contrast, the most unadulterated and least denaturated tissue preparation providing the best antigenicity are frozen sections. Therefore, the objective of this study was to compare different antibodies to extra- and intracellular marker proteins between sections of MMA-embedded and frozen attached palatal mucosa, to be able to select cell biological markers suitable for further immunohistological investigations of wound healing using plastic-embedded human oral mucosa.

\section{Materials and Methods}

Biopsies

To be able to compare the staining pattern of the cell biological markers, three specimens of uninflamed attached mucosa were sampled from the posterior palate region 28 or 18 respectively, of patients undergoing third molar surgery. The biopsies were bisected. One half was processed for frozen sections, and the other half was fixed in $70 \%$ ethanol for $1 \mathrm{~h}$ and prepared for semithin sections after MMA embedding.

\section{Tissue Preparation}

The tissues were processed according to two different methods. For the preparation of frozen sections, the attached mucosal specimens were snap frozen in liquid nitrogen. At $-20^{\circ} \mathrm{C}, 5-$ to $8-\mu \mathrm{m}$ sections were cut on a cryomicrotome, attached to glass slides and air dried at room temperature for $2 \mathrm{~h}$. For the preparation of semithin sections, following fixation in $70 \%$ ethanol, the specimens were dehydrated in 70, 80 and $90 \%$ ethanol, for $0.5 \mathrm{~h}$ each, incubated in MMA (Technovit 8100; Kulzer, Wehr, Germany) for $6-8 \mathrm{~h}$ at $4^{\circ} \mathrm{C}$ and finally embedded in MMA adding the chemical hardener benzoyl peroxide according to a modification of the technique described by Beckstead [1985]. Semithin sections were cut, attached to glass slides and air dried for $2 \mathrm{~h}$ at $37^{\circ} \mathrm{C}$.

\section{Demasking Procedure}

To expose epitopes blocked during the embedding procedure, semithin sections were incubated in $0.1 \%$ trypsin (Sigma, Deisenhofen, Germany) or in $0.4 \%$ pepsin/0.01 N HCl (Sigma; 20) for 15 $\mathrm{min}$ at $37^{\circ} \mathrm{C}$. After enzyme digestion prior to immunohistochemical processing, sections were washed in phosphate-buffered saline (PBS).

\section{Antibodies}

The following antibodies were used as cell biological markers (table 1): anti-CK 4 (C6/B10), anti-CK 14 (CK B1), anti-CK 17 (CK E3), anti-fibronectin (FN-3E2) and anti-laminin (Lam 89; all from Sigma). Anti-CK 5/6 antibody (D5/16B4), anti-CK 1-8 (Ks pan 1-8), anti-CK 13 (Ks 13.1), anti-CK 19 (CK 170.2.14) and antivimentin antibody (V9) were obtained from Boehringer (Mannheim, Germany). The antibody anti-CK 1/2/10/11 (AE2) as well as anti-vinculin (IB-125) were provided by ICN (Meckenheim, Germany) and the anti-collagen IV antibody (Col 94) by Camon 
Table 1. Antibodies used to detect intra- and extracellular matrix components

\begin{tabular}{lllll}
\hline Antigen & Antibody clone & Isotype & Manufacturer & Reference \\
\hline CK 4 & C6/B10 & IgG2b & Sigma & Van Muijen et al. [1986] \\
CK 14 & CK B1 & IgM & Sigma & Caselitz et al. [1986] \\
CK 17 & CK E3 & IgG2b & Sigma & Troyanoysky et al. [1989] \\
CK 5/6 & D5/16B4 & IgG1 & Boehringer & Wild and Mischke [1986] \\
CK 1-8 & Ks pan 1-8 & IgG2a & Boehringer & Quinlan et al. [1985] \\
CK 13 & Ks 13.1 & IgG1 & Boehringer & Moll et al. [1982] \\
CK 19 & CK 170.2.14 & IgG1 & Boehringer & Osborn et al. [1986] \\
CK 1/2/10/11 & AE2 & & ICN & Woodcock-Mitchell et al. [1982] \\
Fibronectin & FN-3E2 & IgG1 & ICN & Yamada and Olden [1978] \\
Laminin & Lam 89 & IgG1 & Sigma & Martin and Timpl [1987] \\
Vimentin & V9 & IgG1 & Boehringer & Osborn et al. [1984] \\
Vinculin & IB-125 & IgG1 & ICN & Geiger [1979] \\
Collagen IV & Col 94 & IgG1 & Camon & Sanes et al. [1990] \\
\hline
\end{tabular}

(Wiesbaden, Germany). All antibodies were initially diluted according to the manufacturers' instructions, and further dilutions $(1: 1,1: 5$ and $1: 10)$ were tested and proved to be necessary on frozen sections. Unspecific immunoglobulin isotypes IgG1, IgG2a, IgG2b and IgM were obtained from ICN.

\section{Immunohistochemical Procedure}

Indirect immunohistochemistry using the avidin-biotin-conjugated immunoperoxidase method (Vectastain; Vector Laboratories, Burlingame, Calif., USA) [Hsu et al., 1981] was carried out. After demasking the epitopes (plastic sections) or after rehydration (cryostat sections), unspecific reactions were blocked with $10 \%$ fetal calf serum (Gibco Laboratories, Life Technologies, Grand Island, N.Y., USA) in PBS for 15 min. Incubation with the primary antibody for $1 \mathrm{~h}$, with the biotin-conjugated secondary antibody (Vectastain Elite Kit; Vector Laboratories) for $45 \mathrm{~min}$ and with the mix of avidin-biotin-conjugated peroxidase (Vectastain Elite Kit) for 30 min followed. Sections were rinsed between each incubation step. The immunoreaction was developed by diaminobenzidine solution $(0.05 \mathrm{mg} / \mathrm{l}$ diaminobenzidine $/ 0.05 \mathrm{M}$ Tris- $\mathrm{HCl}, \mathrm{pH} 7.3 / 0.01 \% \mathrm{H}_{2} \mathrm{O}_{2}$ ) at room temperature. The sections were counterstained with hematoxylin (Merck, Darmstadt, Germany) for $10 \mathrm{~s}$ and mounted in $40 \%$ glycerin (Merck) in PBS. As controls, the staining procedures were carried out either without using any primary antibody or with unspecific immunoglobulins of similar isotypes as the primary antibodies (IgG1, IgG2a, IgG2b and $\operatorname{IgM}$ ).

The specimens were examined with an Axioscope microscope (Zeiss, Jena, Germany) and photographs were taken using a Contax RTS camera (Contax Yashika, Nagano, Japan) with Ektachrom 64 ASA films. The staining signals were located in the epithelial layers as basal, intermediate and superficial, according to Kellokoski et al. [1991].

The degree of correspondence of the antibody reactions between the two tissue preparation methods was analyzed and assessed using a 3-point scale from ++ (large degree of correspondence) to - (no comparable staining results; table 2).

\section{Results}

In order to use various intra- and extracellular markers as tools to investigate graft healing in small human tissue samples, their staining pattern was compared in sections of two different tissue preparations: the MMAembedded and frozen mucosa tissue sections. The different cell biological markers reacted differently on sections from specimens prepared according to the two different methods. With both types of controls (without primary antibody or with immunoglobulin isotypes) neither unspecific background staining nor artificial staining was observed (not shown).

\section{General Findings on Semithin Sections of}

Plastic-Embedded Material of Mucosa: Morphology,

Enzymatic Predigestion and Antibody Dilution

In general, the MMA sections (with a thickness of only $0.5-1 \mu \mathrm{m}$ ) showed better preservation of the cell structure and therefore a better morphology and a better topographic localization of the immune reaction than the frozen sections with a thickness of about 5-7 $\mu \mathrm{m}$. For plastic-embedded material, the staining results depended on the demasking procedure and the antibody dilution. In semithin sections of MMA-embedded mucosa, the best staining results were usually achieved after demasking with $0.1 \%$ trypsin, except for anti-laminin, anti-CK 14 and anti-CK 17 (fig. 1). The latter three antibodies reacted much better with the corresponding antigen after digestion with $0.4 \%$ pepsin in $0.01 \mathrm{~N} \mathrm{HCl}$. These selected enzyme incubations of the semithin sections provided staining results comparable to the frozen sections for 
most of the antibodies tested (table 2). In cryofixed sections, the antibody concentration providing optimal staining results was 5-10 times lower than that of the MMA semithin sections.

\section{Specific Localization of Cell Biological Markers}

in Frozen Sections and in Semithin Sections of

\section{MMA-Embedded Material of Mucosa}

A large degree of correspondence was observed for anti-CK 5/6, anti-CK 13, anti-CK 17, anti-CK 19, anti-CK 1/2/10/11, anti-CK 1-8 and anti-collagen IV; staining results for anti-laminin and anti-CK 14 were comparable (table 2). Especially for the last two markers, background staining was more often higher in the semithin sections than in the frozen sections (not shown). An optimal staining result with very little or no background staining was achieved with anti-CK 5/6 antibody binding to the basal cell layer (fig. 2), anti-CK 1/2/10/11 antibody (fig. 3) and anti-CK 17 antibody (fig. 1) staining the intermediate and superficial cell layer, and anti-collagen IV antibody (fig. 4) staining the basal membrane of the epithelium and vessels in the connective tissue.

No comparable staining results were found for antifibronectin and anti-vimentin between both techniques (not shown). Staining of anti-CK 4 antibody was completely different between semithin and frozen sections. In semithin sections, anti-CK 4 antibody stained the intermediate and superficial layers, whereas it stained cells of the basal layer in frozen sections (fig. 5).

\section{Discussion}

In this immunohistological study, the staining patterns of several antibodies to extra- and intracellular proteins were compared between semithin sections of MMAembedded mucosa and frozen sections to select specific cell biological markers for a subsequent investigation on wound healing in free mucosal grafts.

Plastic embedding was chosen as this technique can be used for tiny specimens, e.g. mucosa [Ten Hacken et al., 1997], and immunohistochemical procedures can be administered [Carmichael et al., 1991]. However, plastic as well as paraffin embedding may alter the antigenicity and therefore immunoreactivity [Ten Hacken et al., 1997] in comparison to frozen sections, the latter being the most unadulterated tissue preparation possible for immunohistochemistry. Changes in immunoreactivity can be due to the fixation proceudure or embedding, or both.
Table 2. Histological localization of immunostaining and their degree of correspondence depending on the tissue preparation technique applied and enzyme demasking

\begin{tabular}{|c|c|c|c|c|}
\hline \multirow{2}{*}{$\begin{array}{l}\text { Antigen } \\
\text { and } \\
\text { antibody - } \\
\text { clone }\end{array}$} & \multicolumn{2}{|c|}{ Localization of immunostaining } & \multirow{2}{*}{$\begin{array}{l}\text { Degree of cor- } \\
\text { respondence } \\
\text { frozen vs. semi- } \\
\text { thin section }\end{array}$} & \multirow{2}{*}{$\begin{array}{l}\text { Enzyme } \\
\text { diges- } \\
\text { tion }\end{array}$} \\
\hline & $\begin{array}{l}\text { cryostate } \\
\text { section }\end{array}$ & $\begin{array}{l}\text { MMA semithin } \\
\text { section }\end{array}$ & & \\
\hline $\begin{array}{l}\text { CK } 4 \\
\text { C6/B10 }\end{array}$ & BCL & ICL, SCL & - & trypsin \\
\hline $\begin{array}{l}\text { CK 5/6 } \\
\text { D5/16B4 }\end{array}$ & BCL, (ICL) & BCL, (ICL) & ++ & trypsin \\
\hline $\begin{array}{l}\text { CK } 13 \\
\text { Ks } 13.1 \\
\end{array}$ & ICL, SCL & ICL, SCL & ++ & trypsin \\
\hline $\begin{array}{l}\text { CK } 14 \\
\text { CK B1 }\end{array}$ & BCL, ICL & BCL, ICL, (SCL) & + & pepsin \\
\hline $\begin{array}{l}\text { CK } 17 \\
\text { CK E3 }\end{array}$ & (ICL) & (ICL) & ++ & pepsin \\
\hline $\begin{array}{l}\text { CK } 19 \\
170.2 .14\end{array}$ & $(\mathrm{BCL})$ & $(\mathrm{BCL})$ & ++ & trypsin \\
\hline $\begin{array}{l}\text { CK 1-8 } \\
\text { Ks pan 1-8 }\end{array}$ & $\begin{array}{l}\text { BCL, ICL, } \\
\text { SCL }\end{array}$ & BCL, ICL, SCL & ++ & trypsin \\
\hline $\begin{array}{l}\text { CK 1,2, 10, } 11 \\
\text { AE2 }\end{array}$ & ICL, SCL & ICL, SCL & ++ & trypsin \\
\hline $\begin{array}{l}\text { Vimentin } \\
\text { V9 }\end{array}$ & $\mathrm{FB}, \mathrm{BM}, \mathrm{CT}$ & not to assess & - & $\begin{array}{l}\text { trypsin } \\
\text { pepsin }\end{array}$ \\
\hline $\begin{array}{l}\text { Fibronectin } \\
\text { FN-3E2 }\end{array}$ & $\mathrm{CT}$ & not to assess & - & $\begin{array}{l}\text { trypsin } \\
\text { pepsin }\end{array}$ \\
\hline $\begin{array}{l}\text { Collagen IV } \\
\text { Col } 94\end{array}$ & $\mathrm{BM}$ & $\mathrm{BM}$ & ++ & trypsin \\
\hline $\begin{array}{l}\text { Laminin } \\
\text { Lam } 89 \\
\end{array}$ & $\mathrm{BM}$ & $\mathrm{BM}, \mathrm{CT}$ & + & pepsin \\
\hline $\begin{array}{l}\text { Vinculin } \\
\text { IB-125 }\end{array}$ & $\mathrm{BM}, \mathrm{CT}$ & not to assess & - & $\begin{array}{l}\text { trypsin } \\
\text { pepsin }\end{array}$ \\
\hline $\begin{array}{l}\quad++=\text { Large } \\
-=\text { no compara } \\
\text { prabasal)/super } \\
\text { FB = fibroblast } \\
\text { of the correspo }\end{array}$ & $\begin{array}{l}\text { degree of cor } \\
\text { ble staining re } \\
\text { ficial cell laye } \\
\text { s; CT = conne } \\
\text { nding cell lay }\end{array}$ & $\begin{array}{l}\text { respondence; + = } \\
\text { esult; BCL/ICL/SC } \\
\text { er of the epitheliu } \\
\text { ective tissue. Pare } \\
\text { er. }\end{array}$ & $\begin{array}{l}\text { mparable stainin } \\
=\text { basal/intermed } \\
\text { BM = basal me } \\
\text { heses indicate sin }\end{array}$ & $\begin{array}{l}\text { ig result; } \\
\text { liate (su- } \\
\text { mbrane; } \\
\text { igle cells }\end{array}$ \\
\hline
\end{tabular}

Fixation limits the selection of antigens/antibodies. It is well known that there are antigens which are not capable of surviving aldehyde fixation and that especially formalin fixation and paraffin embedding may interfere with CK staining. However, aldehyde-labile antigens can be localized using acetone or alcohol fixation [Gigi et al., 1982]. Furthermore, the good morphological preservation which was thought to be virtually impossible without aldehyde fixation [Beckstead, 1985] has already been reported in a comparative study by Carmichael et al. [1991] using aldehyde-free fixation [Carmichael et al., 1991]. This is similar to the very good morphology we observed using $70 \%$ alcohol as fixative. 
Fig. 1. Immunohistochemical staining of anti-CK 17 antibody on frozen (a) and MMA-embedded gingiva using pepsin for demasking (b). There is a similar reaction pattern, but a higher background staining on MMA sections. Scale bars $=25 \mu \mathrm{m}$.

Fig. 2. Immunohistochemical staining of anti-CK 5/6 antibody on frozen (a) and MMA-embedded mucosa (b). There is a similar reaction pattern, with the antibody staining the basal cells of the epithelium. Scale bars $=25 \mu \mathrm{m}$.
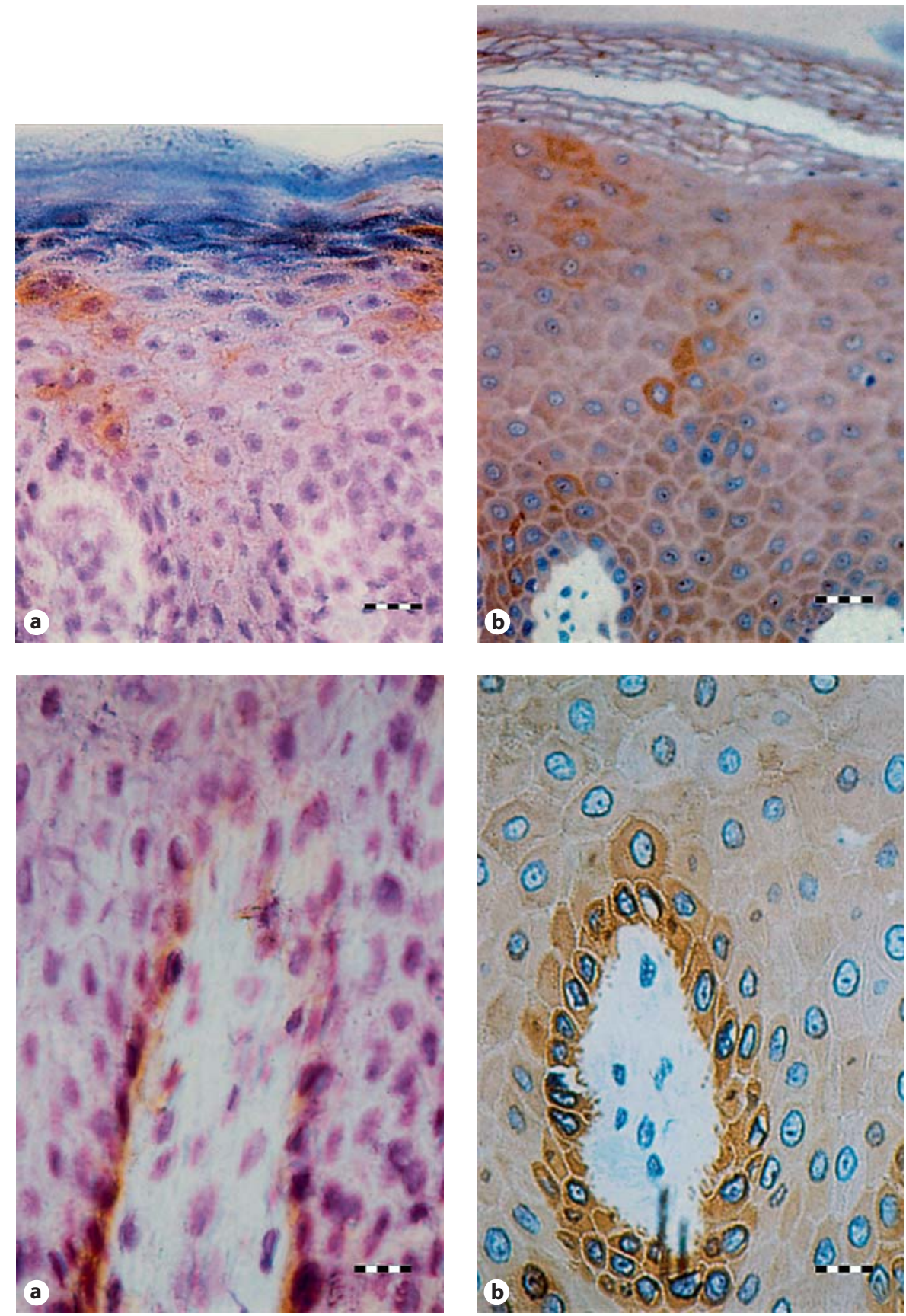

It is known that the amino-terminal ends of the protein chains may bind to methacrylate components treated with the embedding technique and therefore may mask epitopes [Casey et al., 1988]. Several demasking procedures have been suggested. Trypsin or pepsin was successfully used to restore immunoreactivity for most of the antigens in this study, with no negative side effects on the morphology being observed. Other demasking pro- cedures like microwave treatment in citrate buffer or urea have been reported [Shi et al., 1993]. Using these techniques instead or in addition to the enzyme treatment, no positive effect on the demasking procedure was observed for the antigens vinculin, vimentin, fibronectin or CK 4 . No comparable immunostaining pattern could be established for these three antibodies in semithin section of plastic-embedded mucosa. 
Fig. 3. Immunohistochemical staining of AE2 antibody reacting with CK 1/2/10/11 on frozen (a) and MMA-embedded tissue (b). The staining pattern is identical, although the 5 -fold lower antibody concentration on frozen sections renders the reaction less obvious. Arrows = Labeled cells. Scale bars $=25 \mu \mathrm{m}$.
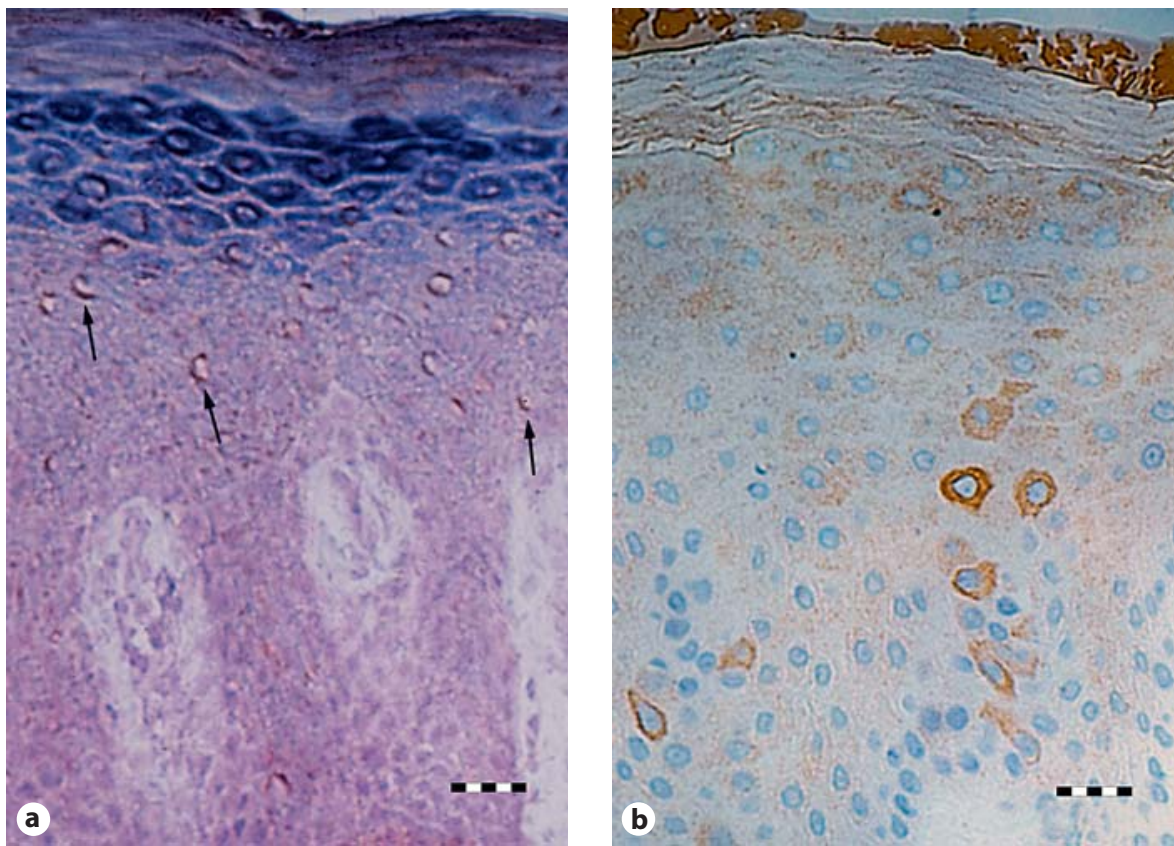

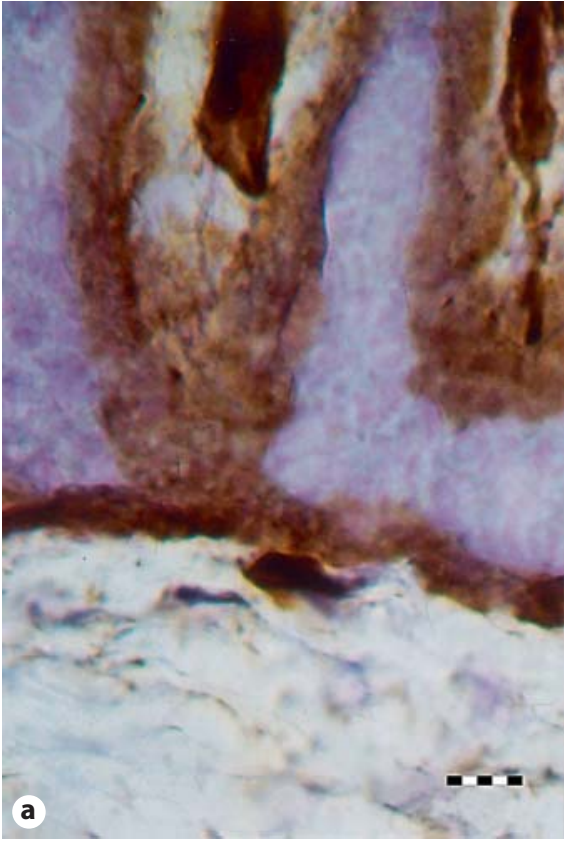

During the immunohistochemical incubation of plastic semithin sections, the primary antibody had to be applied at a higher concentration than the concentration recommended by the manufacturer. This has already been reported by Colbatzky and Hermanns [1987],

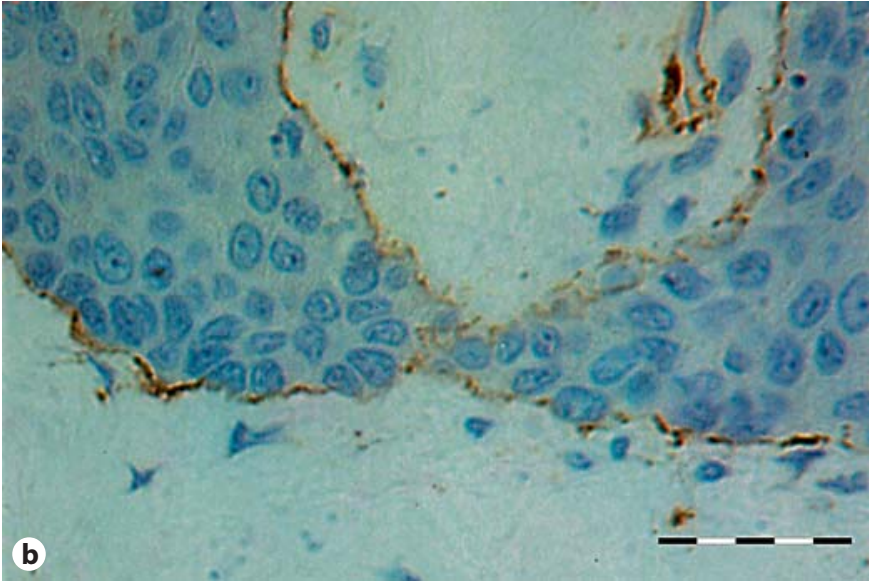

Fig. 4. Immunohistochemical staining of anti-collagen IV antibody on frozen (a) and MMA-embedded material (b). The anticollagen IV antibody reacted similarly, but there is a more distinct patterning on the semithin sections, e.g. of the basal membrane. Scale bars $=25 \mu \mathrm{m}$.

stating the use of primary antibodies with less sensitivity at higher concentrations. The higher concentration partly explains the higher background staining observed for some antibodies (anti-laminin and antiCK 14). 
Fig. 5. Immunohistochemical staining of anti-CK 4 antibody on frozen (a) and MMA-embedded mucosa (b). There is a reciprocal reaction pattern, with staining of the intermediate and superficial cell layers on MMA sections and the basal cells in cryostat sections. Scale bars $=25 \mu \mathrm{m}$.
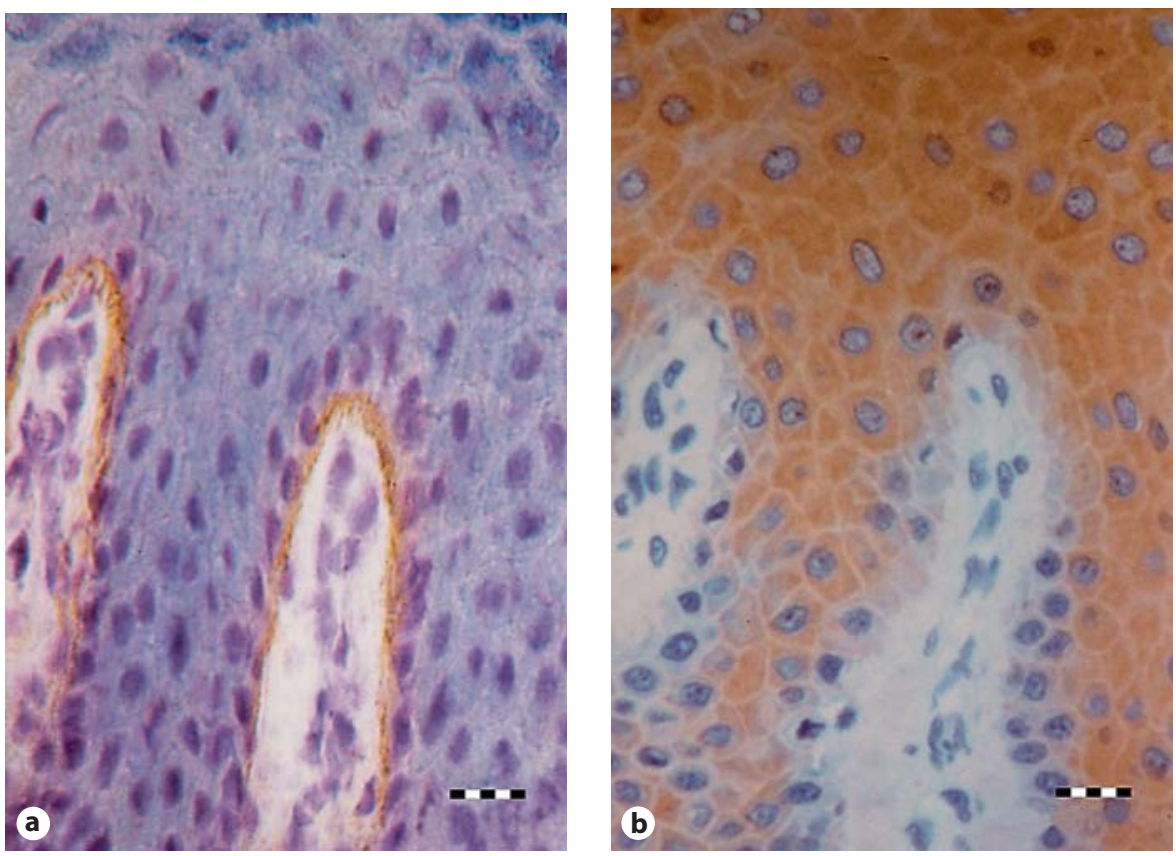

In general, using the fixation and embedding protocol described here, antigenicity remained in 9 of the 12 antibodies tested. Localization of CK $1 / 2 / 10 / 11$, CK 5/6, CK 13, CK 14, CK 17 and CK 19 was similar in both tissue preparations and comparable to the results of previous studies [Shabana et al., 1989; Ouhayoun et al., 1990]. Staining patterns of collagen IV and laminin, components of the subepithelial and vascular basal membrane [Becker et al., 1986], were similar in frozen sections and in sections of MMA-embedded material.

In summary, the comparison of both preparation methods demonstrated that MMA embedding is in general suitable for immunohistochemical examinations. Disadvantages of this method are the background staining and cross-reactions, which were observed for some of the antibodies investigated. Therefore, evaluation of the staining results requires experience in this technique. This aldehyde-free embedding [Casey et al., 1988] enables good preservation of the $\mathrm{CK}$, but certain variations in the staining pattern using different antibodies require an initial comparison of both methods. Advantages of MMA embedding, due to thinner sections, are the better morphology and antigen preservation. Therefore, antigen localization may be superior, e.g. for basal membrane glycoproteins. Additionally, very small biopsies as well as biopsies of hard tissues, e.g. cartilage, can be examined using this method. Antibodies for the intra- and extracellular marker proteins giving an identical staining pattern in both tissue preparations can subsequently be used to study the cell biological and morphological events during the process of wound healing in mucosal transplants after grafting.

\section{Acknowledgments}

This study was supported by grants from the Research Commission of the University Clinic of Freiburg, Germany, and the Federal Ministry of Education and Research (No. 01KI 93146).

References

Alberts, B., D. Bray, J. Lewis, M. Raff, K. Roberts, J.D. Watson ( 1994) Molecular Biology of the Cell, ed 3. London, Garland.

Becker, J., D. Schuppan, E.G. Hahn, G. Albert, P. Reichart (1986) The immunohisto-chemical distribution of collagens type IV, V, VI and of laminin in the human oral mucosa. Arch Oral Biol 31: 179-186.

Beckstead, J.H. (1985) Optimal antigen localization in human tissues using aldehyde-fixed plastic-embedded sections. J Histochem Cytochem 33: 954-958.

Boisnic, S., J.P. Ouhayoun, M.C. Branchet, C. Frances, J.Y. Beranger, Y. LeCharpentier, H. Szpirglas (1995) Alteration of cytokeratin expression in oral lichen planus. Oral Surg Oral Med Oral Pathol Oral Radiol Endod 79: 207-215. 
Bosch, F.X., J.P. Ouhayoun, B.L. Bader, C. Collin, C. Grund, I. Lee, W.W. Franke (1989) Extensive changes in cytokeratin expression patterns in pathologically affected human gingiva. Virchows Arch B Cell Pathol Incl Mol Pathol 58: 59-77.

Carmichael, R.P., C.A.G. McCulloch, G.A. Zarb (1991) Immunohistochemical localization and quantification of desmoplakins I \& II and keratins 1 and 19 in plastic-embedded sections of human gingiva. J Histochem $\mathrm{Cy}$ tochem 39: 519-528.

Caselitz, J., B. Walther, J. Wustrow, G. Seifert, K. Weber, M. Osborn (1986) A monoclonal antibody that detects myoepithelial cells in exocrine glands, basal cells in other epithelia and basal and suprabasal cells in certain hyperplastic tissues. Virchows Arch A Pathol Anat Histopathol 409: 725-738.

Casey, T.T., J.B. Cousar, R.D. Collins (1988) A simplified plastic embedding and immunohistologic technique for immunophenotypic analysis of human hematopoietic and lymphoid tissues. Am J Pathol 131: 183-189.

Colbatzky, F., W. Hermanns (1987) Immunohistochemical demonstration of various antigens in tissues embedded in plastic. Histochem J 19: 589-593.

Geiger, B. (1979) A 130K protein from chicken gizzard: its localization at the termini of microfilament bundles in cultured chicken cells. Cell 18: 193-205.

Gigi, O., B. Geiger, Z. Eshar, R. Moll, E. Schmid, S. Winter, D.L. Schiller, W.W. Franke (1982) Detection of a cytokeratin determinant common to diverse epithelial cells by a broadly cross-reacting monoclonal antibody. EMBO J 1: 1429-1437.

Hsu, S.M., L. Raine, H. Fanger (1981) Use of avidin-biotin-peroxidase complex $(\mathrm{ABC})$ in immunoperoxidase techniques: a comparison between $\mathrm{ABC}$ and unlabeled antibody (PAP) procedures. J Histochem Cytochem 29: 577-580.
Kellokoski, J.K., S.M. Syrjänen, P. Tosi, M. Cintorino, P. Leoncini, K.J. Syrjänen (1991) Cytokeratin pattern in normal and HPV infected oral mucosa in women with genital HPV infections. J Oral Pathol Med 20: 26-31.

Klein, G., M. Ekblom, L. Fecker, R. Timpl, P. Ekblom (1990) Differential expression of laminin A and B chains during development of embryonic mouse organs. Development 110: 823-837.

Lauer, G., R. Mai, W. Pradel, P. Proff, T. Gedrange, J. Beyer (2006) Influence of cyclosporin A on human gingival keratinocytes in vitro. J Craniomaxillofac Surg 2: 116-122.

Martin, G.R., R. Timpl (1987) Laminin and other basement membrane components. Annu Rev Cell Biol 3: 57-85.

Moll, R., W.W. Franke, D.L. Schiller, B. Geiger, R. Krepler (1982) The catalog of human cytokeratins: patterns of expression in normal epithelia, tumors and cultured cells. Cell 31: 11-24.

Osborn, M., E. Debus, K. Weber (1984) Monoclonal antibodies specific for vimentin. Eur J Cell Biol 34: 137-143.

Osborn, M., G. van Lessen, K. Weber, G. Kloppel, M. Altmannsberger (1986) Differential diagnosis of gastrointestinal carcinomas by using monoclonal antibodies specific for individual keratin polypeptides. Lab Invest 55 : 497-504

Ouhayoun, J.P., J.C. Goffaux, M.H. Sawaf, A H.M. Shabana, C. Collin, N. Forest (1990) Changes in cytokeratin expression in gingiva during inflammation. J Periodontal Res 25: $283-292$.

Quinlan, R.A., D.L. Schiller, M. Hatzfeld, T. Achtstätter, R. Moll, J.L. Jocarno, T.M. Magin, W.W. Franke (1985) Patterns of expression and organization of cytokeratin intermediate filaments. Ann NY Acad Sci 455: 282-306.

Sanes, J.R., E. Engvall, R. Butkowski, D.D. Hunter (1990) Molecular heterogeneity of basal laminae: isoforms of laminin and collagen IV at the neuromuscular junction and elsewhere. J Cell Biol 111: 1685-1699.

Shabana, A.H., J.P. Ouhayoun, M.H. Sawaf, N. Forest (1989) A comparative biochemical and immunological analysis of cytokeratin patterns in the oral epithelium of the miniature pig and man. Arch Oral Biol 34: 249259.
Shi, S.R., B. Chaiwun, L. Young, R.J. Lote, C.R. Taylor (1993) Antigen retrieval technique utilizing citrate buffer or urea solution for immunohistochemical demonstration of androgen receptor in formalin-fixed paraffin sections. J Histochem Cytochem 41: 15991604.

Ten Hacken, N.H., R.M. Aleva, B. Rutgers, J. Kraan, H. van Goor, D.S. Postma, W. Times (1997) Techniques in human airway inflammation: differences in plastic-embedded and snap-frozen sections for CD3, CD4, and CD8 immunostaining of bronchial biopsy specimens. Mod Pathol 10: 1043-1046.

Troyanovsky, S.M., V.I. Guelstein, T.A. Tchipysheva, V.A. Krutovskikh, G.A. Bannikov (1989) Patterns of expression of keratin 17 in human epithelia: dependency on cell position. J Cell Sci 93: 419-426.

van Muijen, G.N.P, D.J. Ruiter, W.W. Franke, T. Achtstätter, W.H.B. Haasnoot, M. Ponec, S. O. Warnaar (1986) Cell type heterogeneity of cytokeratin expression in complex epithelia and carcinomas as demonstrated by monoclonal antibodies specific for cytokeratins nos. 4 and 13. Exp Cell Res 162: 97-113.

Weingaertner, J., P. Proff, V. Bienengraeber, T. Gedrange, J. Fanghaenel, K. Lotz (2006) In vivo study of apoptosis as a creative agent of embryonic development of the primary nasal duct in rats. J Craniomaxillofac Surg 2: $3-7$.

Wild, G., D. Mischke (1986) Variation and frequency of cytokeratin polypeptide patterns in human squamous non-keratinizing epithelium. Exp Cell Res 162: 114-126.

Woodcock-Mitchell, J., R. Eichner, W.G. Nelson, T.T. Sun (1982) Immunolocalization of keratin polypeptides in human epidermis using monoclonal antibodies. J Cell Biol 95: 580588 .

Yamada, K.M., K. Olden (1978) Fibronectins adhesive glycoproteins of cell surface and blood. Nature 275: 179-184. 